\title{
PROBLEMATIKA HUKUM KESATUAN PENGELOLAAN HUTAN DI INDONESIA
}

\section{Legal Issues of the Forest Management Unit in Indonesia}

\author{
Dessy Eko Prayitno, ${ }^{* 1}$ Andi Chairil Ichsan ${ }^{2}$ \\ ${ }^{1}$ Mahasiswa Pascasarjana Fakultas Hukum, Universitas Indonesia, Indonesia \\ ${ }^{2}$ Program Studi Kehutanan, Fakultas Pertanian Universitas Mataram, Indonesia \\ *Email: $\underline{\text { de.prayitno@gmail.com }}$
}

Diterima : 11/12/2020, Direvisi : 21/02/2021, Diterbitkan 01/03/2021

\begin{abstract}
The purpose of this research is to analyze the legal issues that cause FMUs to not work optimally in managing forests sustainably. Some of the legal issues analyzed are related to the institution, permit authority, funding, and RPHJP development. This research uses a statute approach and retrospective (ex-post) analysis by examining various laws and regulations in the forestry sector related to FMUs and its implementation. The results of this study indicate that the FMU has serious legal issues in terms of institution, permit authority, funding, and Long-Term Forest Management Plan/RPHJP development. From an institutional perspective, FMUs are at the crossroads of the authorities of the four directorates generals in the Ministry of Environment and Forestry. In terms of authority, FMUs are the spearhead of forest management at the site level, but FMUs do not have adequate authority in managing forests in their areas. Then from the funding side, FMUs are faced with a minimum budget as well as no guarantee of funding for their RPHJP. And finally, in terms of the RPHJP development, FMU faces serious challenges after the enactment of Law No. 23/2014, and laws and regulations overlapping, particularly those related to the implementation of DG Forest Planology Regulation No. P.5/2012..
\end{abstract}

Keywords; Law, forest management unit, forest management.

\begin{abstract}
ABSTRAK
Tujuan penelitian ini adalah untuk menganalisis permasalahan hukum yang menyebabkan $\mathrm{KPH}$ tidak dapat bekerja secara optimal dalam mengelola hutan secara lestari di wilayahnya. Beberapa permasalahan hukum yang dianalisis adalah terkait dengan kelembagaan, kewenangan perizinan, pendanaan, dan penyusunan RPHJP. Penelitian ini menggunakan pendekatan perundang-undangan (statute approach) dan analisis retrospektif (ex-post) dengan mengkaji secara normatif dan implementasinya dari berbagai peraturan perundang-undangan di sektor kehutanan yang terkait dengan KPH. Hasil penelitian ini menunjukkan bahwa KPH memiliki permasalahan hukum serius dari sisi kelembagaan, kewenangan, pendanaan, dan penyusunan RPHJP. Dari sisi kelembagaan, $\mathrm{KPH}$ berada dalam dalam persimpangan kewenangan empat direktorat jenderal di Kementerian Lingkungan Hidup dan Kehutanan. Dari sisi kewenangan, KPH merupakan ujung tombak pengelolaan hutan di tingkat tapak, tetapi KPH tidak memiliki kewenangan memadai dalam mengelola hutan di wilayahnya. Kemudian dari sisi pendanaan, KPH dihadapkan dengan minimnya anggaran sekaligus juga tiadanya jaminan pendanaan bagi RPHJP mereka. Dan terakhir, dari sisi penyusunan RPHJP, KPH mendapatkan tantangan serius pasca diundangkannya UU No. 23/2014, dan adanya tumpang tindih antar
\end{abstract}


peraturan perundang-undangan, khususnya terkait dengan implementasi Perdirjen Planologi Kehutanan No. P.5/2012

Kata kunci; Hukum, kesatuan pengelolaan hutan, pengelolaan hutan.

\section{PENDAHULUAN}

Hutan sebagai modal pembangunan memiliki manfaat yang nyata bagi hidup dan penghidupan bangsa Indonesia, baik manfaat ekologi, sosial budaya, maupun ekonomi secara seimbang dan dinamis (Undang-Undang No. 41 Tahun 1999). Dalam perkembangannya, hutan mendapat tekanan yang begitu kuat sehingga fungsi ekonomis hutan menjadi lebih dominan, sedangkan fungsi ekologis dan fungsi sosial budaya hutan kurang mendapat perhatian (Ekawati S., 2014). Oleh karena itu, Kementerian Lingkungan Hidup dan Kehutanan (KLHK) -dulunya Kementerian Kehutanan, harus mememastikan hutan mampu menjalankan ketiga fungsi hutan (ekologi, sosial budaya, dan ekonomi) secara seimbang agar kelestarian hutan tetap terjaga.

Salah satu upaya yang dilakukan KLHK adalah dengan membentuk wilayah pengelolaan hutan dalam unit-unit pengelolaan hutan (Undang-Undang No. 41 Tahun 1999, Pasal 17), atau yang lebih dikenal dengan kesatuan pengelolaan hutan (KPH). Hariadi Kartodihardjo, dkk (2011) menyebutkan bahwa KPH merupakan konsep perwilayahan pengelolaan hutan untuk mencapai pengelolaan hutan secara optimal, lestari, dan berkeadilan sesuai dengan fungsi pokok dan peruntukkannya. Untuk mencapai tujuan tersebut, KPH diharapkan menjadi pusat informasi mengenai potensi dan ancaman terhadap kawasan hutan, perubahan-perubahannya, serta kondisi sosial budaya masyarakat yang berada di dalam maupun di sekitar hutan (Kartodihardjo H., dkk., 2011).

Pembentukan KPH dilaksanakan dengan mempertimbangkan karakteristik lahan, tipe hutan, fungsi hutan, kondisi daerah aliran sungai, sosial budaya, ekonomi, kelembagaan masyarakat setempat, dan batas administrasi pemerintahan (UndangUndang No. 41 Tahun 1999, Pasal 17). Dalam Penjelasan Pasal 17 ayat (1) menyebutkan bahwa berdasarkan fungsi pokok dan peruntukkannya, KPH dibagi dalam beberapa jenis, antara lain: $\mathrm{KPH}$ lindung (KPHL), $\mathrm{KPH}$ produksi (KPHP), $\mathrm{KPH}$ konservasi (KPHK), KPH kemasyarakatan, $\mathrm{KPH}$ adat, dan kesatuan pengelolaan daerah aliran sungai. Namun demikian, dalam kenyataannya hingga saat ini, hanya terdapat tiga jenis $\mathrm{KPH}$, yaitu: $\mathrm{KPHL}, \mathrm{KPHP}$, dan KPHK.

Pembangunan KPH kali pertama dimulai pada tahun 2010 dengan dimasukkannya rencana pembangunan KPH dalam Rencana Pembangunan Jangka Menengah Nasional Tahun 2010-2014 dan Rencana Strategis Kementerian Kehutanan Tahun 2010-2014 (Suharjito D., 2017). Hingga Mei 2019, terdapat $542 \mathrm{KPHL}$ dan KPHP yang telah ditetapkan wilayahnya, dan 413 diantaranya telah ditetapkan kelembagaannya. Dari 542 $\mathrm{KPH}$, telah disahkan 235 rencana pengelolaan hutan jangka panjang (RPHJP) untuk 235 $\mathrm{KPH}$, sedangkan 307 RPHJP masih dalam proses pengesahan oleh Menteri Lingkungan Hidup dan Kehutanan (http://kph.menlhk.go.id/sinpasdok/pages/pencariandata).

Meskipun secara kuantitas, jumlah KPH yang sudah terbentuk hingga 2019 mencapai 542 dari target 629 (Renstra Dirjen Konservasi Sumber Daya Alam dan Ekosistem Tahun 2015-2019), namun pembangunan KPH masih menghadapi berbagai kendala, antara lain: kendala terkait dengan tata hubungan kerja KPH dengan UPT KLHK, sumber daya manusia, mekanisme pendanaan dan keorganisasian, dukungan kebijakan pusat dan daerah terkait dengan kerjasama para pihak dan konsolidasi strategis dengan program nasional (Suharjito D., 2017), perbedaan persepsi mengenai KPH, belum memadainya regulasi terkait $\mathrm{KPH}$, lemahnya koordinasi para pengambil kebijakan, dan rendahnya partisipasi dari masyarakat (Sadam S. Husen, dkk., 2018). Kendala-kendala tersebut kemudian berdampak pada efektifitas kinerja $\mathrm{KPH}$ dalam mengelola hutan di masing-masing wilayah $\mathrm{KPH}$. 
Studi yang dilakukan Bappenas pada tahun 2019 menunjukkan bahwa peran atau kinerja KPH dalam meningkatkan tutupan lahan dan mengurangi kebakaran hutan tidaklah signifikan. Dalam studi tersebut dinyatakan bahwa, "tidak ditemukan bukti empiris yang kuat yang menunjukkan bahwa keberadaan KPH bisa meningkatkan tutupan lahan." (Adrison V., dkk., 2019). Begitu pula dalam upaya mengurangi kebakaran hutan. Pengaruh keberadaan $\mathrm{KPH}$ terhadap pengurangan kebakaran hutan hanya terjadi di wilayah Sumatera dan Kalimantan, sedangkan di Bali dan Nusa Tenggara justru sebaliknya, setelah terbentuknya KPH justru kebakaran hutan cenderung lebih luas dibanding sebelum terbentuknya KPH (Adrison V., dkk., 2019).

Laporan studi Bappenas tersebut tak pelak menimbulkan tanda tanya besar terhadap efektifitas keberadaan $\mathrm{KPH}$ sebagai satu-satunya entitas pengelola hutan di tingkat tapak. Hal ini mengingat banyak kalangan yang meyakini bahwa KPH merupakan konsep ideal kelembagaan pengelola hutan di tingkat tapak yang mengakomodir nilai-nilai good forestry governance dalam rangka mewujudkan tata kelola hutan yang optimal dan lestari (Suwarno E., 2015). Selain itu, KPH juga dinilai memiliki banyak peran strategis dalam penyelesaian konflik tenurial, pemanfaatan hutan, mendukung komitmen nasional dalam penurunan gas emisi rumah kaca, intermediary actor untuk pemanfaatan dana hibah luar negeri, rehabilitasi hutan, dan sebagai wujud nyata desentralisasi dibidang kehutanan (Ali Djajono, 2018).

Penelitian ini akan menganalisis mengenai permasalahan hukum yang menyebabkan KPH tidak dapat bekerja secara optimal dalam mengelola hutan di wilayahnya. Secara spesifik, permasalahan hukum yang akan dipotret mencakup permasalahan hukum terkait dengan kelembagaan, kewenangan, pendanaan, dan penyusunan RPHJP.

\section{METODE}

Penelitian ini merupakan penelitian hukum dengan menggunakan pendekatan undang-undang (statute approach) dan analisis kebijakan retrospektif (ex-post) dengan mengkaji secara normatif dan implementasinya dari berbagai peraturan perundangundangan di sektor kehutanan, khususnya yang terkait dengan $\mathrm{KPH}$. Penelitian dengan menggunakan analisis kebijakan yang bersifat retrospektif (ex-post), merupakan proses analisis yang dilakukan setelah aksi kebijakan dijalankan. Secara konseptual, analisis kebijakan merupakan suatu alat untuk mensintesa informasi untuk dipakai dalam merumuskan alternatif dan preferensi kebijakan yang dinyatakan secara komparatif maupun deskriptif (Dunn 2003). Data penelitian ini dikumpulkan melalui kajian dokumen (Mulyana D. 2006, Ichsan, 2020) dan penelusuran data-data dan penelitian melalui berbagai media, seperti internet, jaringan dokumentasi hukum yang dimiliki oleh instansi pemerintah. Analisis kualitatif dalam penelitian ini mengacu pada analisis data model interaktif yang dikembangkan oleh Miles \& Huberman(1992), dengan tiga sub proses yang saling terkait, meliputi: reduksi data, penyajian data dan pengambilan kesimpulan/verifikasi.

\section{HASIL DAN PEMBAHASAN}

\section{A. Kerangka Hukum KPH}

Menurut Putu Oka Ngakan, dkk., (2008), konsep KPH sudah mulai ada sejak diberlakukannya Undang-Undang No. 5 Tahun 1967 tentang Ketentuan-Ketentuan Pokok Kehutanan (UU No. 5/1967). Dalam Undang-Undang tersebut, KPH didefinisikan sebagai kesatuan pemangkuan hutan (Undang-Undang No. 5 Tahun 1967, Pasal 10 ayat (1)). Ahmad Maryudi (2016) menyatakan bahwa amanat pembangunan KPH kemudian dipertegas dalam Undang-Undang No. 41 Tahun 1999 tentang Kehutanan (UU No. 
41/1999). Berbeda dengan UU No. 5/1967 yang menggunakan frasa pemangkuan, UU No. 41/1999 menggunakan frasa pengelolaan. Hingga saat ini, KPH dengan frasa pemangkuan hanya digunakan oleh Perum Perhutani yang mengelola hutan di Pulau Jawa. Sedangkan KPH dengan frasa pengelolaan digunakan oleh seluruh unit pengelola hutan ditingkat tapak di seluruh Indonesia.

Pasal 17 UU No. 41/1999 mengatur KPH sebagai unit pengelolaan hutan. Secara lengkap bunyi Pasal 17 tersebut sebagai berikut:

(1) Pembentukan wilayah pengelolaan hutan dilaksanakan untuk tingkat:

a. Provinsi;

b. Kabupaten/kota; dan

c. Unit pengelolaan

(2) Pembentukan wilayah pengelolaan hutan tingkat unit pengelolaan dilaksanakan dengan mempertimbangkan karakteristik lahan, tipe hutan, fungsi hutan, kondisi daerah aliran sungai, sosial budaya, ekonomi, kelembagaan masyarakat setempat termasuk masyarakat hukum adat dan batas administrasi pemerintahan.

(3) Pembentukan unit pengelolaan hutan yang melampaui batas administrasi pemerintahan karena kondisi dan karakteristik serta tipe hutan, penetapannya diatur secara khusus oleh Menteri.

Dalam penjelasan Pasal 17 ayat (1) kemudian dijelaskan secara lebih rinci mengenai wilayah pengelolaan hutan tingkat unit pengelolaan, yaitu:

“... kesatuan pengelolaan hutan terkecil sesuai fungsi pokok dan peruntukkannya, yang dapat dikelola secara efisien dan lestari, antara lain: kesatuan pengelolaan hutan lindung (KPHL), kesatuan pengelolaan hutan produksi (KPHP), kesatuan pengelolaan hutan konservasi (KPHK), kesatuan pengelolaan hutan kemasyarakatan (KPHKM), kesatuan pengelolaan hutan adat (KPHA), dan kesatuan pengelolaan daerah aliran sungai (KPDAS)."

Pengaturan KPH dalam UU No. 41/1999 ini kemudian dirinci lebih lanjut dalam Peraturan Pemerintah No. 6 Tahun 2007 tentang Tata Hutan dan Penyusunan Rencana Pengelolaan Hutan, serta Pemanfaatan Hutan (PP No. 6/2007) yang kemudian diubah dengan Peraturan Pemerintah No. 3 Tahun 2008. Dalam PP No. 6/2007 tersebut, BAB II mengatur mengenai: (a) jenis-jenis $\mathrm{KPH}$, yaitu KPHK, KPHL, dan KPHP (Pasal 5); (b) kriteria, kewenangan untuk menetapkan, dan tata cara penetapan KPH (Pasal 6 jo Pasal 7 jo Pasal 8); (c) organisasi KPH (Pasal 8 ayat 3, ayat 4, ayat 5, dan ayat 6); (d) tugas dan fungsi KPH (Pasal 9); dan (e) dukungan infrastruktur dan pendanaan KPH (Pasal 10).

Lebih rinci mengenai pengaturan KPH dalam PP No. 6/2007 dapat diuraikan sebagai berikut: pertama, kriteria pembentukan $\mathrm{KPH}$. Terdapat tiga kriteria utama dalam penetapan $\mathrm{KPH}$, yaitu: (a) ditetapkan dalam satu atau lebih fungsi pokok hutan (Pasal 6 ayat (1)). Artinya, satu unit KPH bisa mengelola satu fungsi pokok hutan atau lebih. Misalnya, satu unit KPH mengelola hutan lindung saja, atau satu unit KPH mengelola hutan lindung, hutan produksi, dan hutan konservasi sekaligus karena di dalamnya terdapat tiga fungsi hutan tersebut; (b) ditetapkan dalam satu wilayah administrasi atau lintas wilayah administrasi pemerintahan (Pasal 6 ayat (1)). Misalnya, wilayah KPH dapat terdiri dari wilayah yang berada dalam satu wilayah kabupaten/kota saja atau wilayahnya berada lintas kabupaten/kota; dan (c) dalam hal KPH terdiri dari lebih dari satu fungsi pokok hutan, maka penetapan KPH dilakukan berdasarkan fungsi yang luasnya dominan (Pasal 6 ayat (2)). Misalnya, satu KPH terdiri dari hutan lindung dan hutan produksi, dimana areal terluasnya adalah hutan lindung, maka ditetapkan sebagai KPHL, pun sebaliknya jika areal yang lebih luas adalah hutan produksi, maka ditetapkan sebagai 
KPHP. Pengaturan lebih rinci mengenai pembentukan KPH diatur dalam Peraturan Menteri Kehutanan No. P.6/Menhut-II/2009 tentang Pembentukan Wilayah Kesatuan Pengelolaan Hutan (Permenhut No. 6/2009), khususnya Pasal 4 - Pasal 10.

Kedua, kewenangan menetapkan KPH. Penetapan KPH mencakup dua hal, yaitu penetapan wilayah KPH dan penetapan organisasi $\mathrm{KPH}$. Wilayah $\mathrm{KPH}$ ditetapkan oleh Menteri dengan memperhatikan efisiensi dan efektifitas pengelolaan hutan dalam satu wilayah daerah aliran sungai atau satu kesatuan ekosistem (Pasal 7 ayat (1)). Sedangkan penetapan organisasi KPH dilakukan sesuai dengan masing-masing tingkat kewenangan, yaitu pemerintah pusat, pemerintah provinsi, dan/atau pemerintah kabupaten kota (Pasal 8 ayat (1)). Pemerintah pusat berwenang menetapkan organisasi KPHK dan KPHL/KPHP yang wilayah kerjanya lintas provinsi (Pasal 8 ayat (2)). Pemerintah provinsi berwenang menetapkan organisasi KPHL/KPHP yang wilayah kerjanya lintas kabupaten/provinsi (Pasal 8 ayat (3)). Sedangkan pemerintah kabupaten/kota berwenang menetapkan organisasi KPHL/KPHP yang wilayah kerjanya berada dalam satu wilayah kabupaten/kota (Pasal 8 ayat (4)). Pengaturan lebih rinci mengenai pembentukan KPH diatur dalam Permenhut No. 6/2009, khususnya Pasal 11 - Pasal 13.

Ketiga, tugas dan fungsi KPH. Pasal 9 ayat (1) PP No. 6/2007 mengatur tugas dan fungsi $\mathrm{KPH}$, yaitu: (a) menyelenggarakan pengelolaan hutan, yang meliputi: tata hutan dan penyusunan rencana pengelolaan hutan, pemanfaatan hutan, penggunaan kawasan hutan, rehabilitasi hutan dan reklamasi, dan perlindungan hutan dan konservasi alam; (b) menjabarkan kebijakan kehutanan nasional, provinsi, dan kabupaten/kota bidang kehutanan untuk diimplementasikan; (c) melaksanakan kegiatan pengelolaan hutan di wilayahnya mulai dari perencanaan, pengorganisasian, pelaksanaan dan pengawasan, serta pengendalian; (d) melaksanakan pemantauan dan penilaian atas pelaksanaan kegiatan pengelolaan hutan di wilayahnya; dan (e) membuka peluang investasi guna mendukung tercapainya tujuan pengelolaan hutan.

Pengaturan lebih rinci mengenai tugas dan fungsi $\mathrm{KPH}$, diatur dalam Peraturan Menteri Kehutanan No. P.6/Menhut-II/2010 tentang Norma, Standar, Prosedur, dan Kriteria Pengelolaan Hutan Pada Kesatuan Pengelolaan Hutan Lindung dan Kesatuan Pengelolaan Hutan Produksi (Permenhut No. 6/2010). Namun demikian, Permenhut No. 6/2010 ini hanya mengatur KPHL dan KPHP, sedangkan untuk KPHK, hingga Penelitian ini disusun, belum memiliki NSPK-nya sendiri. Permenhut No. 6/2010 ini juga dirinci lebih lanjut dalam Peraturan Direktur Jenderal Planologi Kehutanan No. P.5/VII-WP3H/2012 tentang Petunjuk Teknis Tata Hutan dan Penyusunan Rencana Pengelolaan Hutan Pada Kesatuan Pengelolaan Hutan Lindung dan Kesatuan Pengelolaan Hutan Produksi (Perdirjen Planologi Kehutanan No. P.5/2012).

Keempat, dukungan infrastruktur dan pendanaan $\mathrm{KPH}$ yang diberikan oleh masingmasing tingkat pemerintahan sesuai dengan kewenangannya, melalui alokasi anggaran yang bersumber dari APBN, APBD, dan/atau dana lain yang tidak mengikat. Pengaturan lebih rinci mengenai dukungan infrastruktur dan pendanaan diatur dalam Peraturan Menteri Lingkungan Hidup dan Kehutanan No. P.20/Menlhk-II/2015 tentang Fasilitasi Biaya Operasional Kesatuan Pengelolaan Hutan.

\section{B. Kelembagaan KPH Diampu Empat Direktorat Jenderal Berpotensi Menyebabkan Tumpang Tindih Kewenangan}

Di tingkat nasional, kelembagaan $\mathrm{KPH}$ terkait erat dengan struktur birokrasi yang melingkupinya (Maryudi A., 2016). Dalam konteks ini, KPH merupakan bagian dari struktur birokrasi KLHK. Dalam struktur birokrasi KLHK saat ini, terdapat empat direktorat jenderal yang menangani kelembagaan KPH, yaitu: Direktorat Jenderal Planologi Kehutanan dan Tata Lingkungan (Ditjen PKTL), Direktorat Jenderal Konservasi Sumber Daya Alam dan Ekosistem (Ditjen KSDAE), Direktorat Jenderal Pengendalian Daerah Aliran Sungai dan Hutan Lindung (Ditjen PDAS-HL), dan Direktorat Jenderal Pengelolaan Hutan Produksi 
Lestari (Ditjen PHPL). Keempat direktorat jenderal ini dibentuk dan didesain dalam rangka mewadahi atau mengelola program pemerintah terkait KPH pada masing-masing direktorat jenderal.

Dalam Peraturan Menteri Lingkungan Hidup dan Kehutanan No. P.18/MenlhkII/2015 tentang Organisasi dan Tata Kerja Kementerian Lingkungan Hidup dan Kehutanan disebutkan bahwa Ditjen PKTL berwenang dalam pembentukan wilayah KPH (Pasal 137 huruf a), kewenangan ini diikuti dengan adanya Direktorat Rencana, Penggunaan dan Pembentukan Wilayah Pengelolaan Hutan (Pasal 138 huruf b). Direktorat ini bertanggungjawab dalam pembentukan wilayah pengelolaan hutan dan memberikan asistensi kepada KPH dalam menyelenggarakan tata hutan dan penyusunan rencana pengelolaan hutan (Pasal 158 jo Pasal 159). Kemudian Ditjen KSDAE bertanggungjawab terhadap KPHK (Pasal 268), Ditjen PDAS-HL bertanggungjawab terhadap KPHL (Pasal 390), dan Ditjen PHPL bertanggungjawab terhadap KPHP (Pasal 517).

Sebagai sebuah sistem birokasi, keberadaan empat direktorat jenderal yang menangani $\mathrm{KPH}$ berpotensi untuk memunculkan tumpang tindih tugas dan kewenangan, yang pada akhirnya akan bermuara pada konflik kewenangan. Konflik kewenangan tidak hanya pada pelaksanaan tugas dan kewenangan, tetapi juga pada persaingan untuk mendapatkan kekuasaan, sumber daya (manusia dan anggaran), dan pengaruh.

Potensi konflik kewenangan ini sangat besar terjadi, mengingat desain $\mathrm{KPH}$ dimungkinkan untuk mengelola lebih dari satu fungsi pokok hutan. Dalam konteks tersebut, satu KPH yang mengelola dua atau lebih fungsi pokok hutan akan diampu oleh dua atau lebih direktorat jenderal. Atau bisa juga terjadi sebaliknya, hanya ada satu direktorat jenderal yang akan bertanggungjawab terhadap KPH tersebut. Misalnya, KPHP yang juga memiliki areal hutan lindung, maka Ditjen PHPL hanya akan mengalokasikan anggaran khusus untuk areal hutan produksi, sedangkan areal hutan lindung tidak akan mendapatkan alokasi anggaran, karena Ditjen PHPL merasa itu bukan kewenangannya, melainkan kewenangan Ditjen PDAS-HL. Situasi ini tentu saja tidak ideal dalam kerangka pengelolaan hutan yang lestari dan berkelanjutan. Dan permasalahan kelembagaan KPH yang dinaungi empat direktorat jenderal ini berpotensi untuk semakin memperkeruh kelembagaan $\mathrm{KPH}$.

\section{KPH: Pengelola Hutan Di Tingkat Tapak, Minus Kewenangan Perizinan}

$\mathrm{KPH}$ sebagai unit pengelola kawasan hutan di tingkat tapak dituntut untuk bisa menjawab tantangan untuk mewujudkan pengelolaan hutan secara lestari. Namun demikian, desain kelembagaan $\mathrm{KPH}$ saat ini menempatkan $\mathrm{KPH}$ sebagai pengelola hutan yang tidak memiliki kewenangan perizinan. Jika menelaah lebih rinci mengenai berbagai peraturan yang mengatur mengenai kewenangan pemberian perizinan pengelolaan hutan, maka KPH tidak memiliki peran yang signifikan dalam proses pemberian izin, meskipun areal yang diberikan izin berada dalam lingkup pengelolaan KPH. Sebagai contoh dalam perhutanan sosial, Pasal 61 Peraturan Menteri Lingkungan Hidup dan Kehutanan No. P.83/MENLHK/SETJEN/KUM.1/10/2016 tentang Perhutanan Sosial menyebutkan bahwa peran $\mathrm{KPH}$ masih sebatas menerima tembusan terhadap permohonan hak pengusahaan hutan desa (HPHD), izin usaha pemanfaatan hutan kemasyarakatan (IUPHKm), izin usaha pemanfaatan hasil hutan kayu pada hutan tanaman rakyat (IUPHHK-HTR), kemitraan kehutanan, dan hutan adat, menjadi anggota tim verifikasi permohonan, membantu pemerintah dalam memfasilitasi pemegang HPHD, IUPHKm, dan IUPHHK-HTR dalam proses pengusulan permohonan, penguatan kelembagaan, peningkatan kapasitas, pembentukan koperasi, tata batas areal kerja, penyusunan rencana kerja, pembiayaan, pasca panen, pengembangan usaha, dan akses pasar. 
Dalam spektrum yang lebih luas, KPH ditempatkan sebagai UPT Dinas Kehutanan Provinsi yang mana semua kewenangannya dalam mengelola hutan berada di bawah kewenangan Dinas Kehutanan Provinsi. Tetapi di sisi lain, Dinas Kehutanan Provinsi yang memiliki kewenangan dalam mengelola hutan, justru tidak memiliki bidang atau divisi yang bertanggungjawab dalam mengelola hutan. Mayoritas bidang-bidang di Dinas Kehutanan Provinsi diisi dengan bidang-bidang sesuai dengan kegiatan-kegiatan yang terpisah satu sama lainnya, seperti bidang rehabilitasi, bidang perlindungan dan konservasi, bidang perkebunan, dan bidang penyuluhan (PermenLHK No. P.74/Menlhk/Setjen/Kum.1/8/2016, Lampiran 3). Dan apabila ditelaah lebih jauh, bidang-bidang ini didesain untuk mengerjakan program atau proyek dari pemerintah pusat, sehingga nomenklatur bidangbidang juga disesuaikan dengan program pemerintah pusat maupun struktur organisasi di tingkat pusat. Menurut Sulistya Ekawati (2014), penempatan KPH sebagai UPT Dinas Kehutanan juga dianggap sebagai salah satu cara tapping anggaran dari pemerintah pusat, baik yang berasal dari DIPA KLHK maupun dana alokasi khusus (DAK) bidang kehutanan.

\section{Problematika Dukungan Anggaran Bagi KPH}

Hasil studi di beberapa KPH, juga memberikan gambaran bahwa terdapat dua permasalahan serius dalam konteks penganggaran $\mathrm{KPH}$, yaitu: minimnya anggaran bagi $\mathrm{KPH}$ dan RPHJP KPH yang tidak bermuara pada alokasi anggaran bagi KPH (Ichsan AC, 2018). Terkait dengan minimnya anggaran bagi KPH. Anggaran yang dikeluarkan pemerintah pusat untuk KPH memang mengalami peningkatan antar waktu, dari 15 miliar di tahun 2013 menjadi hampir 210 miliar di tahun 2018 (Adrison V., 2019). Namun demikian, anggaran 210 miliar jika dibagi rata $542 \mathrm{KPH}$, maka masing-masing $\mathrm{KPH}$ hanya mendapatkan anggaran sebesar Rp. 380-an juta. Anggaran Rp. 380-an juta ini tentu saja sangat kecil dibandingkan dengan beban kerja yang ditanggung oleh $\mathrm{KPH}$.

Terkait dengan RPHJP KPH yang tidak bermuara pada alokasi anggaran bagi KPH terjadi karena perencanaan penganggaran $\mathrm{KPH}$ memiliki dua pendekatan. Dua model pendekatan perencanaan dan penganggaran kehutanan tersebut adalah: (a) perencanaan yang berbasis pada Rencana Kehutanan (nasional, provinsi, dan kabupaten/kota), yang kemudian dijabarkan dalam RPHJP dan RPHJPd sebagaimana diatur dalam PP No. 6/2007; dan (b) perencanaan yang berbasis rencana strategis dan rencana kerja kementerian sebagaimana diatur dalam Undang-Undang No. 25 Tahun 2004 tentang Sistem Perencanaan Pembangunan Nasional dan Peraturan Menteri Kehutanan No. P.28/Menhut-II/2006 tentang Sistem Perencanaan Kehutanan (Muhammad Maulana, 2018).

Dua model pendekatan perencanaan penganggaran $\mathrm{KPH}$ tersebut di atas tidak disertai dengan mekanisme sinkronisasi keduanya. Alhasil, RPHJP KPH yang merupakan dokumen perencanaan pengelolaan hutan oleh KPH tidak mendapatkan alokasi anggaran, karena alokasi anggaran diberikan berdasarkan dokumen perencanaan yang berbasis rencana strategis dan rencana kerja kementerian (Muhammad Maulana, 2018). Dalam konteks ini, alokasi anggaran KPH cenderung tidak sesuai dengan kebutuhan masingmasing $\mathrm{KPH}$ sebagaimana tertuang dalam RPHJP dan RPHJPd, karena anggaran yang diberikan kepada $\mathrm{KPH}$ bersifat top down untuk melaksanakan kegiatan yang menjadi program atau mandat pemerintah di tingkat pusat.

\section{E. Problematika Dalam Penyusunan RPHJP}

Penyusunan RPHJP KPH menjadi persoalan tersendiri akibat dari: (a) diundangkannya Undang-Undang No. 23 Tahun 2014 tentang Pemerintahan Daerah (UU No. 23/2014); dan (b) tumpang tindih atau benturan antar peraturan perundang-undangan. Terkait dengan diundangkannya UU No. 23/2014, secara umum, banyak kalangan 
berpendapat bahwa UU No. 23/2014 ini akan berdampak pada pembangunan KPH, mengingat pembangunan $\mathrm{KPH}$ mayoritas dilakukan di tingkat kabupaten/kota (Kushartati Budiningsih, $d k k ., 2015)$.

Terkait dengan penyusunan RPHJP, pengundangan UU No. 23/2014 berdampak pada beberapa hal, antara lain: pertama, Pasal 14 ayat (1) dan ayat (2) UU No. 23/2014 mengatur bahwa urusan pemerintahan dibidang kehutanan, penyelenggaraannya dibagi antara pemerintah pusat dan daerah provinsi, kecuali terkait dengan pengelolaan taman hutan raya kabupaten/kota menjadi kewenangan kabupaten/kota. Kemudian Pasal 15 mengatur lebih lanjut pembagian urusan pemerintahan antara pemerintah pusat dan pemerintah daerah (provinsi/kabupaten/kota). Khusus bidang kehutanan, terdapat enam sub-urusan pemerintahan, yaitu: perencanaan kehutanan, pengelolaan hutan, konservasi sumber daya alam hayati dan ekosistemnya, pendidikan dan pelatihan, penyuluhan dan pemberdayaan masyarakat dibidang kehutanan, pengelolaan daerah aliran sungai, dan pengawasan kehutanan. Perubahan pembagian urusan pemerintahan bidang kehutanan menurut UU No. 32/2004 dan menurut UU No. 23/2014 ditunjukkan dalam Tabel 1 berikut ini.

Tabel 1. Perubahan Pembagian Urusan Pemerintahan Bidang Kehutanan Table 1. Changes in Government Affairs Division of Forestry Sector

\begin{tabular}{|c|c|c|c|c|c|c|}
\hline \multirow{2}{*}{ Urusan Pemerintahan } & \multicolumn{3}{|c|}{ UU No. 32/2004 } & \multicolumn{3}{|c|}{ UU No. 23/2014 } \\
\hline & Pusat & Prov & Kab & Pusat & Prov & $\mathrm{Kab}$ \\
\hline $\begin{array}{l}\text { Penyelenggaraan Inventarisasi } \\
\text { Hutan }\end{array}$ & & $\sqrt{ }$ & $\sqrt{ }$ & $\sqrt{ }$ & & \\
\hline $\begin{array}{l}\text { Penyelenggaraan Pengukuhan } \\
\text { Hutan }\end{array}$ & 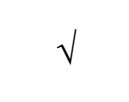 & $\sqrt{ }$ & $\sqrt{ }$ & $\sqrt{ }$ & & \\
\hline $\begin{array}{l}\text { Penyelenggaraan Penatagunaan } \\
\text { Kawasan Hutan }\end{array}$ & $\sqrt{ }$ & $\sqrt{ }$ & $\sqrt{ }$ & $\sqrt{ }$ & & \\
\hline $\begin{array}{l}\text { Penyelenggaraan Pembentukan } \\
\text { Wilayah Pengelolaan Hutan }\end{array}$ & $\sqrt{ }$ & $\sqrt{ }$ & $\sqrt{ }$ & $\sqrt{ }$ & & \\
\hline $\begin{array}{l}\text { Penyelenggaraan Rencana } \\
\text { Kehutanan Nasional }\end{array}$ & $\sqrt{ }$ & $\sqrt{ }$ & $\sqrt{ }$ & $\sqrt{ }$ & & \\
\hline Penyelenggaraan Tata Hutan & $\sqrt{ }$ & $\sqrt{ }$ & $\sqrt{ }$ & $\checkmark$ & $\sqrt{ }$ & \\
\hline $\begin{array}{l}\text { Penyelenggaraan Rencana } \\
\text { Pengelolaan Hutan }\end{array}$ & $\sqrt{ }$ & $\sqrt{ }$ & $\sqrt{ }$ & $\sqrt{ }$ & $\sqrt{ }$ & \\
\hline $\begin{array}{l}\text { Penyelenggaraan Rehabilitasi } \\
\text { dan Reklamasi Hutan }\end{array}$ & $\sqrt{ }$ & $\sqrt{ }$ & $\sqrt{ }$ & $\sqrt{ }$ & $\sqrt{ }$ & \\
\hline $\begin{array}{l}\text { Penyelenggaraan Perlindungan } \\
\text { Hutan }\end{array}$ & $\sqrt{ }$ & $\sqrt{ }$ & $\sqrt{ }$ & $\sqrt{ }$ & $\sqrt{ }$ & \\
\hline $\begin{array}{l}\text { Penyelenggaraan Pengolahan } \\
\text { dan Penatausahaan Hasil Hutan } \\
\text { Penyelenggaraan Pengelolaan }\end{array}$ & $\sqrt{ }$ & $\sqrt{ }$ & $\sqrt{ }$ & $\sqrt{ }$ & $\sqrt{ }$ & \\
\hline $\begin{array}{l}\text { Kawasan Hutan dengan Tujuan } \\
\text { Khusus }\end{array}$ & $\sqrt{ }$ & $\sqrt{ }$ & $\sqrt{ }$ & $\sqrt{ }$ & $\sqrt{ }$ & \\
\hline $\begin{array}{l}\text { Penyelenggaraan Pengelolaan } \\
\text { Kawasan Suaka Alam dan } \\
\text { Kawasan Pelestarian Alam }\end{array}$ & $\sqrt{ }$ & $\sqrt{ }$ & $\sqrt{ }$ & $\sqrt{ }$ & $\sqrt{ }$ & $\sqrt{ }$ \\
\hline $\begin{array}{l}\text { Penyelenggaraan Konservasi } \\
\text { Tumbuhan dan Satwa Liar } \\
\text { Penyelenggaraan Pemanfaatan }\end{array}$ & $\sqrt{ }$ & $\sqrt{ }$ & $\sqrt{ }$ & $\sqrt{ }$ & $\sqrt{ }$ & \\
\hline $\begin{array}{l}\text { Secara Lestari Kondisi } \\
\text { Lingkungan Kawasan Pelestarian } \\
\text { Alam }\end{array}$ & $\sqrt{ }$ & $\sqrt{ }$ & $\sqrt{ }$ & $\sqrt{ }$ & $\sqrt{ }$ & \\
\hline
\end{tabular}




\begin{tabular}{lcccccc}
\hline \multirow{2}{*}{ Urusan Pemerintahan } & \multicolumn{3}{c}{ UU No. 32/2004 } & \multicolumn{3}{c}{ UU No. 23/2014 } \\
\cline { 2 - 7 } & Pusat & Prov & Kab & Pusat & Prov & Kab \\
\hline $\begin{array}{l}\text { Penyelenggaraan Pemanfaatan } \\
\text { Jenis Tumbuhan dan Satwa Liar }\end{array}$ & $\sqrt{y y y y y}$ & $\sqrt{ }$ & $\sqrt{ }$ & $\sqrt{ }$ & $\sqrt{ }$ \\
$\begin{array}{l}\text { Pendidikan daan Pelatihan, } \\
\text { Penyuluhan dan Pemberdayaan }\end{array}$ & & & & & & $\sqrt{ }$ \\
Masyarakat di Bidang Kehutanan & & & & $\sqrt{ }$ & \\
Pengelolaan DAS & $\sqrt{ }$ & $\sqrt{ }$ & $\sqrt{ }$ & $\sqrt{ }$ & $\sqrt{ }$ \\
Pengawasan Kehutanan & $\sqrt{ }$ & $\sqrt{ }$ & $\sqrt{ }$ & $\sqrt{ }$ & \\
\hline
\end{tabular}

Sumber : Eno Suwarno, dkk. (2018)

Berdasarkan tabel di atas, pasca lahirnya UU No. 23/2014, terdapat perubahan kewenangan bidang kehutanan antara pemerintah pusat, provinsi, dan kabupaten/kota. Khusus terkait dengan kewenangan dalam pelaksanaan tata hutan dan penyusunan rencana pengelolaan hutan, perubahan kewenangan terletak pada kewenangan penyelenggaraan inventarisasi hutan yang sebelumnya menjadi kewenangan pemerintah provinsi/ kabupaten/kota, pasca UU No. 23/2014 menjadi kewenangan pemerintah pusat saja.

Perubahan kewenangan penyelenggaraan inventarisasi hutan oleh pemerintah pusat ini bertentangan dengan hampir semua peraturan sektor kehutanan sebagaimana ditunjukkan dalam Tabel 2 di bawah ini. Peraturan-peraturan tersebut mengatur bahwa inventarisasi hutan merupakan bagian dari kegiatan tata hutan yang menjadi kewenangan pemerintah provinsi. Perubahan kewenangan ini berimplikasi pada terhambatnya proses penyusunan dan pengesahan RPHJP, karena harus menunggu selesainya inventarisasi hutan yang dilaksanakan oleh pemerintah pusat, dalam hal ini adalah KLHK.

Tabel 2. Peraturan Perundang-Undangan yang Mengatur Kewenangan Penyelenggaraan Inventarisasi Hutan Oleh KPH

Table 2. Implementation of Regulations Governing Authority Forest Inventory By KPH

\section{No Peraturan Perundang-Undangan}

1 PP No. 44 Tahun 2004 tentang Perencanaan Kehutanan

2 PP No. 6 Tahun 2007 tentang Tata Hutan dan Penyusunan Rencana Pengelolaan Hutan, serta Pemanfaatan Hutan

3 Permenhut No. P.10/Menhut-II/2006 tentang Inventarisasi Hutan Produksi Tingkat Unit Pengelolaan Hutan

4 Permenhut No. P.67/Menhut-II/2006 tentang Kriteria dan Standar Inventarisasi Hutan

5 Permenhut No. P.33/Menhut-II/2009 jo Permenhut P.5/Menhut-II/2011 tentang Pedoman Inventarisasi Hutan Menyeluruh Berkala (IHMB) Pada Usaha Pemanfaatan Hasil Hutan Kayu Pada Hutan Produksi

6 Permenhut No. P.6/Menhut-II/2010 tentang NSPK Pengelolaan Hutan Pada KPHL dan $\mathrm{KPHP}$

Selain itu, UU No. 23/2014 mengatur bahwa kewenangan perencanaan kehutanan menjadi wewenang pemerintah pusat. Perencanaan kehutanan ini meliputi: penyelenggaraan inventarisasi hutan, penyelenggaraan pengukuhan kawasan, penyelenggaraan penatagunaan kawasan, penyelenggaraan pembentukan wilayah 
pengelolaan hutan, dan penyelenggaraan rencana kehutanan nasional. Penyelenggaraan kegiatan bidang kehutanan berada di domain pemerintah pusat, sementara pemerintah provinsi hanya berperan sebagai pelaksana. Tidak adanya atau minimnya kewenangan perencanaan kehutanan oleh pemerintah provinsi menyebabkan minimnya pengalokasian anggaran pemerintah provinsi kepada $\mathrm{KPH}$. Kondisi ini menyebabkan $\mathrm{KPH}$ bergantung kepada pendanaan yang bersumber dari APBN.

Kedua, kompleksitas hubungan antara KPH, dinas kehutanan provinsi/kabupaten/kota, dan KLHK. Menurut Sugiharto, Ed. (2014) kompleksitas hubungan tersebut disebabkan beberapa faktor, antara lain: (a) penerapan yang tidak konsisten dari Peraturan Menteri Dalam Negeri No. 61 Tahun 2010 tentang Tata Kelola Organisasi $\mathrm{KPH}$ karena berbagai kesiapan dan rendahnya respon pemerintah daerah, dukungan dana yang terbatas oleh pemerintah daerah, perencanaan program yang kurang harmonis antara KPH dan kantor dinas kehutanan daerah; dan (b) apabila ada keharusan $\mathrm{KPH}$ dibentuk sebagai bagian dari organisasi pemerintah daerah, maka keberadaannya akan tergantung pada persetujuan politik Dewan Perwakilan Rakyat Daerah, sebagaimana terjadi pada 4 KPHP yang berada di Kabupaten Berau, Kalimantan Timur.

Ketiga, perubahan terhadap kemampuan KPH dalam mengelola wilayah akibat dari adanya perubahan kewenangan. Dalam situasi seperti ini, akan ada KPH yang akan mengelola lebih dari satu unit pengelolaan akibat dari penggabungan beberapa $\mathrm{KPH}$ menjadi satu $\mathrm{KPH}$. Penggabungan $\mathrm{KPH}$ ini juga memunculkan tantangan dalam penggabungan RPHJP (Adrison V., 2019).

Keempat, sinkronisasi program dan kegiatan di setiap tingkat pemerintahan. Sinkronisasi program dan kegiatan ini penting dilakukan karena berdampak pada keputusan pengalokasian anggaran untuk $\mathrm{KPH}$. Jika sinkronisasi program dan kegiatan tidak dilakukan, maka pelaksanaan program dan kegiatan $\mathrm{KPH}$ berpotensi tidak dapat dilaksanakan.

Permasalahan lain dalam kaitannya dengan penyusunan RPHJP adalah terkait dengan tumpang tindih atau benturan antar peraturan perundang-undangan, hal ini terutama dikaitkan dengan Perdirjen Planologi Kehutanan No. P.5/2012. Setidaknya terdapat empat permasalahan hukum terkait dengan Perdirjen Planologi Kehutanan No. P.5/2012 ini, yaitu: pertama, Perdirjen Planologi Kehutanan No. P.5/2012 mengatur bahwa pelaksanaan tata hutan dan penyusunan RPHJP dilaksanakan oleh: (a) organisasi KPHL dan KPHP; atau (b) balai pemantapan kawasan hutan (BPKH). Ketentuan ini bertentangan dengan Pasal 11 ayat (1) Permenhut No. P.6/Menhut-II/2010 yang mengatur bahwa penyusunan RPHJP dilakukan oleh Kepala KPHL dan KPHP. Dibukanya opsi pelaksanaan tata hutan dan penyusunan RPHJP oleh BPKH dilatar belakangi pemikiran bahwa KPH belum siap untuk secara mandiri melaksanakan tata hutan dan menyusun RPHJP, oleh karenanya BPKH dapat mengambil alih tugas Kepala KPH tersebut. Implikasinya adalah rendahnya rasa memiliki KPH terhadap dokumen RPHJP tersebut, tidak adanya pemahaman utuh dari KPH terhadap RPHJP, dan lain sebagainya.

Kedua, inventarisasi hutan masih menitikberatkan pada potensi kayu (KLHK, 2019). Perdirjen Planologi Kehutanan No. P.5/2012 sebenarnya mengatur bahwa inventarisasi hutan diarahkan untuk mendapatkan data dan informasi mengenai: (a) status, penggunaan dan penutupan lahan; (b) jenis tanah, kelerengan lapangan/topografi; (c) iklim; (d) hidrologi/tata air, bentang alam dan gejala-gejala alam; (e) kondisi sumber daya manusia dan demografi; dan (f) jenis potensi dan sebaran flora (Perdirjen Planologi Kehutanan No. P.5/2012). Namun demikian, dalam pengaturannya, elaborasi mengenai tata cara pelaksanaan inventarisasi hanya difokuskan kepada inventarisasi kayu dan inventarisasi sosial budaya masyarakat. Sedangkan tata cara perolehan dan analisis data dan informasi lainnya tidak dielaborasi lebih jauh, meskipun dalam format laporan perolehan dan analisis 
data dan informasi mencakup seluruh informasi mengenai: letak dan luas wilayah $\mathrm{KPH}$, keadaan fisik, topografi, geologi, tanah, iklim, kependudukan (kondisi sosial, ekonomi, dan budaya masyarakat), aksesibilitas, dan bentang alam spesifik. Dan, saat ini, secara praktik, desain inventarisasi hutan dan implementasinya masih menitikberatkan pada potensi kayu (timber based) yang berpedoman pada inventarisasi hutan nasional (national forest inventory). Informasi sumber daya hutan lainnya terutama hasil hutan bukan kayu, satwa liar, jasa lingkungan dan wisata alam yang berada di wilayah $\mathrm{KPH}$ memiliki porsi yang minim, jika hanya dengan mengandalkan pelaksanaan inventarisasi hutan dengan metode tersebut. Sementara inventarisasi sosial budaya yang dilakukan terbatas hanya memposisikan masyarakat sebagai objek dan bukan sebagai subjek yang bersama-sama $\mathrm{KPH}$ dapat menentukan tujuan dan kondisi yang diinginkan.

Ketiga, RPHJP belum mencerminkan multiguna hutan. Hal ini sebagaimana diulas sebelumnya bahwa inventarisasi hutan masih fokus pada inventarisasi kayu. Hal ini tentunya bertentangan dengan UU No. 41/1999. Jika mencermati salah satu tujuan UU No. 41/1999 sebagaimana disebutkan dalam Pasal 3 huruf b, dinyatakan bahwa penyelenggaraan kehutanan dilakukan dengan, "mengoptimalkan aneka fungsi hutan yang meliputi fungsi konservasi, fungsi lindung, dan fungsi produksi untuk mencapai manfaat lingkungan, sosial, budaya, dan ekonomi, yang seimbang dan lestari." Kemudian Pasal 6 UU No. 41/1999 mengatur bahwa hutan memiliki tiga fungsi, dan pemerintah menetapkan hutan berdasarkan tiga fungsi tersebut, yaitu hutan konservasi, hutan lindung, dan hutan produksi. Selain tiga fungsi tersebut, Pasal 8 UU No. 41/1999 mengatur bahwa pemerintah juga dapat menetapkan kawasan hutan tertentu untuk tujuan khusus, seperti penelitian dan pengembangan, pendidikan dan latihan, dan religi dan budaya. Kemudian untuk hutan konservasi dapat terdiri dari kawasan hutan suaka alam, kawasan hutan pelestarian alam, dan taman buru. Pengaturan mengenai RPHJP yang harus mencerminkan multiguna hutan ini relevan ketika melihat pengaturan bahwa sangat dimungkinkan satu $\mathrm{KPH}$ mengelola lebih dari satu fungsi hutan. Satu KPH bisa mengelola hutan dengan tiga fungsi sekaligus. Sebagai contoh, KPH lindung di dalamnya juga ada kawasan hutan yang berfungsi produksi atau konservasi. Begitu juga sebaliknya bahwa KPH produksi, di dalamnya juga ada kawasan untuk perlindungan dan konservasi.

Keempat, tidak adanya sanksi bagi kepala KPH yang tidak menyusun RPHJP. Apabila merujuk data Sinpasdok $\mathrm{KPH}+$, dari $542 \mathrm{KPH}$ yang telah ditetapkan wilayahnya, baru $235 \mathrm{KPH}$ atau sekitar $43 \%$ dari seluruh $\mathrm{KPH}$ yang telah memiliki RPHJP (http://kph.menlhk.go.id/sinpasdok/pages/pencariandata). Angka ini termasuk rendah mengingat Perdirjen Planologi Kehutanan No. P.5/2012 sudah diundangkan sejak tahun 2012. Salah satu indikasi penyebab rendahnya keberadaan RPHJP ini adalah karena Perdirjen Planologi Kehutanan No. P.5/2012 tidak mengatur sanksi bagi KPH yang tidak segera menyusun RPHJP.

\section{KESIMPULAN DAN SARAN}

Berdasarkan uraian pada bagian-bagian sebelumnya, Penelitian ini mengambil kesimpulan, pertama, KPH yang diampu oleh empat direktorat jenderal berpotensi untuk memunculkan tumpang tindih tugas dan kewenangan, yang pada akhirnya akan bermuara pada konflik kewenangan. Konflik kewenangan tidak hanya pada pelaksanaan tugas dan kewenangan, tetapi juga pada persaingan untuk mendapatkan kekuasaan, sumber daya (manusia dan anggaran), dan pengaruh. Kedua, KPH sebagai unit pengelola kawasan hutan di tingkat tapak dituntut untuk bisa menjawab tantangan untuk mewujudkan pengelolaan hutan lestari, namun demikian KPH tidak memiliki kewenangan perizinan. Dalam konteks ini, pemerintah menempatkan KPH dalam posisi yang tak berdaya tetapi dilain pihak terus menuntut kinerja optimal $\mathrm{KPH}$ dalam mengelola hutan secara lestari. 
Ketiga, selain lemah secara kelembagaan, KPH juga lemah dari sisi anggaran, baik karena minimnya anggaran, maupun tidak adanya alokasi anggaran untuk pelaksanaan RPHJP akibat adanya dualisme perencanaan dan penganggaran $\mathrm{KPH}$. Keempat, penyusunan RPHJP KPH juga menjadi problematika tersendiri, mulai dari RPHJP yang tidak mencerminkan multiguna hutan, inventarisasi hutan masih menitikberatkan pada potensi kayu, pengesahan yang lambat, rasa memiliki yang rendah terhadap RPHJP karena disusunkan oleh BPKH, tidak adanya alokasi anggaran terhadap RPHJP, dan tidak adanya sanksi bagi $\mathrm{KPH}$ yang tidak segera menyusun RPHJP.

Dari kesimpulan sebagaimana diuraikan di atas, Penelitian ini memberikan beberapa saran sebagai berikut: pertama, kedepan, KLHK harus melakukan restrukturisasi organisasi KLHK dengan menggabungkan KPH dalam satu atau maksimal dua direktorat jenderal, yaitu Ditjen PKTL yang bertanggungjawab dalam pembentukan wilayah pengelolaan hutan, dan satu direktorat jenderal yang akan mengampu ketiga $\mathrm{KPH}$, yaitu $\mathrm{KPHK}, \mathrm{KPHL}$, dan KPHP. Kedua, KLHK harus memperkuat peran dan kewenangan KPH dalam perizinan. KPH merupakan institusi "penguasa" hutan di tingkat tapak, sehingga harus diperkuat kewenangannya dalam pengambilan kebijakan, terutama yang menyangkut mengenai perizinan pengelolaan hutan di areal kerja $\mathrm{KPH}$. Ketiga, terkait dengan perencanaan penganggaran, KLHK harus: (a) mengalokasikan anggaran yang memadai bagi $\mathrm{KPH}$; dan (b) membuat mekanisme sinkronisasi antara RPHJP dengan dokumen rencana strategis dan rencana kerja kementerian, sehingga penganggaran terhadap RPHJP dapat terpenuhi. Keempat, melakukan revisi terhadap Perdirjen Planologi Kehutanan No. P.5/2012 untuk menyelesaikan beberapa problematika penyusunan RPHJP, yaitu: (a) RPHJP yang tidak mencerminkan multiguna hutan, sehingga kedepan RPHJP harus disusun dengan menekankan pada aspek multiguna hutan; (b) inventarisasi hutan yang masih menitikberatkan pada potensi kayu, sehingga kedepan panduan inventarisasi hutan harus menyeluruh dari aspek sosial, ekonomi, dan ekologi, sehingga diharapkan inventarisasi hutan dapat dilakukan secara menyeluruh terhadap potensi dan ancaman terhadap hutan; (c) rasa memiliki yang rendah terhadap RPHJP karena disusunkan oleh BPKH, sehingga kedepan kewenangan menyusun RPHJP harus dimandatkan kepada pemerintah provinsi dan menugaskannya kepada $\mathrm{KPH}$ sesuai dengan mandat Permenhut No. P.6/Menhut-II/2010 dan PerMenLHK No. P.98.MENLHK/SETJEN/KUM.1/11/2018; (d) tidak adanya alokasi anggaran terhadap RPHJP, sehingga kedepan harus ada jaminan bahwa terhadap RPHJP yang disusun KPH, maka akan ada alokasi anggaran untuk pelaksanaan RPHJP tersebut; dan (e) tidak adanya sanksi bagi KPH yang tidak segera menyusun RPHJP, dengan demikian, kedepan harus ada sanksi bagi KPH yang tidak segera menyusun RPHJP.

\section{DAFTAR PUSTAKA}

Adrison, Vid. dkk., (2019). "Final Report Pengaruh Investasi Pembangunan Kesatuan Pengelolaan Hutan terhadap Tutupan Hutan dan Kebakaran Hutan." Jakarta : Bappenas.

Budiningsih, Kushartati, et.al., (2015), Tipologi dan Strategi Pengembangan Kesatuan Pengelolaan Hutan di Indonesia, Jurnal Analisis Kebijakan Kehutanan Vol 12, No. 3), (https://ejournal.forda-mof.org/latihan/index.php/JAKK/article/view/1351/0).

Djajono, Ali, (2018). Peran Strategis Kesatuan Pengelolaan Hutan (KPH), AGROINDONESIA Vol. XIV, No. 676, 20-26.

Dunn, William N. (2003). Analisa Kebijakan Publik. Yogyakarta: Gajahmada University Press.

Ekawati, Sulistya, (2014). "Apakah yang Dimaksud Dengan Kesatuan Pengelolaan Hutan $(\mathrm{KPH})$ ?" dalam Operasionalisasi Kesatuan Pengelolaan Hutan (KPH): Langkah Awal Menuju Kemandirian, Jakarta: Penerbit Kanisius 
Ekawati, Sulistya, (2014). "Pembangunan KPH di Indonesia" dalam Operasionalisasi Kesatuan Pengelolaan Hutan (KPH): Langkah Awal Menuju Kemandirian, Jakarta: Penerbit Kanisius.

http://kph.menlhk.go.id/sinpasdok/pages/pencariandata

Husen, Sadam S. dkk, (2018). Penilaian Kinerja Pembangunan Kesatuan Pengelolaan Hutan Produksi Awota di Provinsi Sulawesi Selatan, Jurnal Hutan dan Masyarakat, Vol. 10 (2): 283-289. (http://dx.doi.org/10.24259/jhm.v10i2.4941).

Indonesia, Undang-Undang No. 41 Tahun 1999 tentang Kehutanan, Penjelasan Umum.

Indonesia, Peraturan Pemerintah No. 6 Tahun 2007 tentang Tata Hutan dan Penyusunan Rencana Pengelolaan Hutan, serta Pemanfaatan Hutan.

Indonesia. Undang-Undang No. 5 Tahun 1967 tentang Ketentuan-Ketentuan Pokok Kehutanan.

Indonesia, Undang-Undang No. 23 Tahun 2014 tentang Pemerintahan Daerah.

Ichsan, A. C., Aji, I. M. L., Anwar, H., Waru, T., \& Febryano, I. G. (2020). The implementation of conservation village model program in mount Rinjani National Park (A Regulation Perspective). Ecology, Environment and Conservation, 26(3), 11001109.

Ichsan, A. C. (2018). Kinerja Pembangunan Kesatuan Pengelolaan Hutan Lindung Sungai Wain dan DAS Manggar di Provinsi Kalimantan Timur. Jurnal Belantara, 1(1), 225265.

Kartodihardjo, Hariadi. Dkk. (2011). Pembangunan Kesatuan Pengelolaan Hutan (KPH): Konsep, Peraturan Perundangan dan Implementasi, Direktorat Jenderal Planologi Kehutanan, Direktorat Wilayah Pengelolaan dan Penyiapan Areal Pemanfaatan Kawasan Hutan, Kementerian Lingkungan Hidup dan Kehutanan, Jakarta.

Kementerian Kehutanan, Perdirjen No. P.5/VII-WP3H/2012 tentang Petunjuk Teknis Tata Hutan dan Penyusunan Rencana Pengelolaan Hutan Pada KPHL dan KPHP.

Kementerian Lingkungan Hidup dan Kehutanan, Peraturan Menteri Lingkungan Hidup dan Kehutanan No. P.18/Menlhk-II/2015 tentang Organisasi dan Tata Kerja Kementerian Lingkungan Hidup dan Kehutanan.

Kementerian Lingkungan Hidup dan Kehutanan, Peraturan Menteri Lingkungan Hidup dan Kehutanan No. P.83/MENLHK/SETJEN/KUM.1/10/2016 tentang Perhutanan Sosial.

Kementerian Lingkungan Hidup dan Kehutanan, Peraturan Menteri Lingkungan Hidup dan Kehutanan No. P.74/Men/hk/Setjen/Kum.1/8/2016 tentang Pedoman Nomenklatur Perangkat Daerah Provinsi dan Kabupaten.

Kementerian Lingkungan Hidup dan Kehutana, Rencana Strategis Direktorat Jenderal Konservasi Sumber Daya Alam dan Ekosistem Tahun 2015-2019.

Kementerian Lingkungan Hidup dan Kehutanan, Kertas Kebijakan: Penyempurnaan Kebijakan Perencanaan dan Operasionalisasi KPH, Direktorat Rencana, Penggunaan dan Pembentukan Wilayah Pengelolaan Hutan, Direktorat Jenderal Planologi Kehutanan dan Tata Lingkungan, Kementerian Lingkungan Hidup dan Kehutanan, Jakarta.

Maryudi, Ahmad. (2019) Arahan Tata Hubungan Kelembagaan Kesatuan Pengelolaan Hutan (KPH) di Indonesia, Jurnal IImu Kehutanan Volume 10 No.1 - Januari-Maret 2016, (https://doi.org/10.22146/jik.12632)

Maulana,Muhammad. 2018. Potret Penyusunan Rencana dan Anggaran Kesatuan Pengelolaan Hutan, USAID BIJAK.

Miles, B. Mathew dan Michael Huberman. 1992. Analisis Data Kualitatif Buku Sumber Tentang Metode-metode Baru. Jakarta: UIP.

Mulyana D. 2006. Metode Penelitian Kualitatif. Bandung (ID): PT Remaja Rosdakarya.

Ngakan, Putu Oka. dkk., Menerawang Kesatuan Pengelolaan Hutan di Era Otonomi Daerah, Bogor: Center for International Forestry Research, Governance Brief January 2008.

Sugiharto, Ed., (2014) Strategi Pengembangan KPH Dan Perubahan Struktur Kehutanan Indonesia, Direktorat Wilayah Pengelolaan dan Penyiapan Areal Pemanfaatan 
Kawasan Hutan, Direktorat Jenderal Planologi Kehutanan, Kementerian Lingkungan Hidup dan Kehutanan,

Suharjito, Didik. (2017). Kesatuan Pengelolaan Hutan (KPH): Kebijakan, Implementasi, dan Masa Depan, Jakarta: Multistakeholder Forestry Programme 3 (MFP3) dan Dewan Kehutanan Nasional (DKN).

Suwarno, Eno. (2015). Apakah KPH Dapat Memperbaiki Tata Kelola Hutan Indonesia, Jurnal Wahana Forestra Vol. 10, No. 2, (https://doi.org/10.31849/forestra.v10i2.226).

Suwarno, Eno. et.al.,(2018) Panduan Penilaian Kinerja Pembangunan dan Pelaksanaan Pengelolaan Hutan di Wilayah KPH dengan Menggunakan Kriteria dan Indikator FWI 2.0, Forest Watch Indonesia, Bogor. 